Zeszyty Naukowe Szkoły Głównej Gospodarstwa Wiejskiego

Ekonomika i Organizacja Gospodarki Żywnościowej nr 119, 2017: 37-50

DOI 10.22630/EIOGZ.2017.119.24

\title{
Marcin Idzik
}

Wydział Nauk Ekonomicznych

Szkoła Główna Gospodarstwa Wiejskiego w Warszawie

\section{Pozycja konkurencyjna banków spółdzielczych w segmencie mikroprzedsiębiorstw}

\section{Wstęp}

Środowisko bankowców reprezentujące segment banków spółdzielczych w Polsce coraz częściej zwraca uwagę na nasilającą się konkurencję na rynku bankowym [Monitor Bankowy 2017]. Jednocześnie zgodnie z dominującą opinią w środowisku spółdzielców banki spółdzielcze wyszły obronną ręką z kryzysu bankowego, a w obszarze swojego działania zachowują konkurencyjność wobec banków komercyjnych [Komisja Nadzoru Finansowego 2013]. Opinia ta jest stosunkowo powszechna, można jednak przyjąć, iż może stanowić znaczący czynnik ryzyka dla oceny sytuacji banków spółdzielczych, gdyż często jest to tylko tło dla przyszłych tendencji, a nie ich bezpośredni wyznacznik [Zygierewicz 2012]. W opinii Węcławskiego „...banki spółdzielcze czekają poważne wyzwania, którym muszą sprostać, aby utrzymać swoje udziały w rynku" [2010]. Na wyczerpującą odpowiedź czeka także pytanie o wskazanie kierunków reformy modelu biznesowego bankowości spółdzielczej i wskazania, do czego te zmiany mają prowadzić [Szambelańczyk 2016].

W opiniach ekspertów czynnik kapitałowy, nowe reguły gry wynikające $\mathrm{z}$ regulacji oraz spadające marże uznawane są za główne z hamulców ekspansji banków spółdzielczych [Pawlonka 2012]. Czynniki te są ważne, jednak maskują inne uwarunkowania, które w dyskusji nad sytuacją rynkową banków spółdzielczych nie są podnoszone, a od których zależy ich pozycja w przyszłości [Siudek i in 2013]. Banki spółdzielcze muszą budować swoją pozycję konkurencyjna, przede wszystkim poprzez efektywne wykorzystanie swoich zasobów, a konkurencyjność banków spółdzielczych powinna być przedmiotem pomiaru i oceny [Woźniewska 2010]. 
Lokalny charakter, deficyty $\mathrm{w}$ oferowaniu nowoczesnych usług rozliczeniowych oraz inwestycyjnych, jak i słabości wizerunkowe powodują, iż banki spółdzielcze omijane są przez potencjalnych klientów MSP. Na tereny jeszcze do niedawna obsługiwane wyłącznie przez banki spółdzielcze coraz częściej wkraczają banki komercyjne, z którymi konkurencyjnie zwykle przegrywają banki spółdzielcze [Idzik 2015]. Analiza sytuacji rynkowej z perspektywy zakresu oraz segmentów obsługiwanych klientów wskazuje na ryzyko utraty zdobytej pozycji na rynku, a obserwowane w statystykach zmiany pozycji banków spółdzielczych są egzemplifikacją procesów zachodzących w ich relacjach z ich klientami [Perek i Pawlonka 2014]. O ile obecnie jeszcze sytuacja rynkowa banków spółdzielczych nie jest z perspektywy udziałów rynkowych alarmująca, o tyle tendencje czynniki, od których zależą udziały w rynku, wskazują na konieczność podjęcia działań w zakresie odpowiedzi banków spółdzielczych na zmieniające się otoczenie konkurencyjne [Idzik 2016].

Banki spółdzielcze są liderem w obsłudze rolników, ale zajmują także silną pozycję $\mathrm{w}$ segmencie mikroprzedsiębiorstw, obsługując 17\% wszystkich $\mathrm{z}$ niespełna $2 \mathrm{mln}$ aktywnych mikroprzedsiębiorstw w Polsce [Firmy w świecie finansów 2016]. Banki spółdzielcze skupione dotychczas na obsłudze swojego niszowego sektora [Szelągowska 2012], muszą z coraz większą uwagą odpowiadać na działania konkurencyjne ze strony banków komercyjnych oraz zmiany, jakie następują w portfolio własnych klientów [Twaróg 2013]. Banki spółdzielcze poddawane są coraz silniejszej presji konkurencyjnej ze strony banków komercyjnych czy SKOK-ów wchodzących w tradycyjne dla bankowości spółdzielczej nisze rynkowe, jak i ze strony samych BS-ów [Kasiewicz i in. 2013].

W ocenie Woźniewskiej przez wiele lat głównym źródłem przewagi na rynku był bazujący na prawie spółdzielczym specyficzny model biznesu i związane $\mathrm{z}$ tym bliskie relacje z klientami. Obecnie czynniki te tracą na znaczeniu [Woźniewska 2011], a budowanie modelu wspólnoty wokół marki nie daje rezultatów w postaci przypływu nowych klientów. Jak zauważa Janina Harasim, w takiej sytuacji wśród czynników przewagi konkurencyjnej banku ważną funkcję pełnią elementy marketingowe: oferowane produkty, warunki cenowe, wygodne dla klienta kanały dystrybucji i środki promocji, jakość usług bankowych, wizerunek i reputacja banku, komunikacja oraz nowoczesne technologie [Harasim 2009]. Jednak jak zaznacza Nowacka „w większości banków spółdzielczych nie ma w ogóle komórek marketingowych i niewiele $\mathrm{z}$ nich opracowuje plany marketingowe" [Nowacka 2009]. W efekcie zdobyty, ważny i ceniony kapitał reputacyjny nie jest efektywnie wykorzystywany we wspieraniu pozycji rynkowej banków spółdzielczych oraz nie buduje wspólnoty wokół marki, tak jak miało to miejsce wiele lat temu. Należy przy tym mieć na uwadze, że tworzona przez 
wiele lat społeczność wokół marki nie była strategią marketingową, a strategią biznesowa, wyrażającą się w zaangażowaniu członków w realne działania banków spółdzielczych. Obecnie tworzenie strategii społecznościowej wymaga takiego zarządzania w efekcie, którego będzie następowało tworzenie popytu, wytwarzanie produktu i zapewnianie wspólnoty emocjonalnej wokół marki [Meerman 2012].

\section{Cel i metody badań}

Głównym celem opracowania jest odpowiedź na pytanie, jaka jest obecnie pozycja konkurencyjna banków spółdzielczych oraz w jakim stopniu gwarantuje stabilny i długotrwały rozwój w przyszłości. Ponadto poszukiwano odpowiedzi na pytanie: w jakim zakresie banki spółdzielcze mają możliwość trwałego kreowania tendencji rozwojowych oraz skutecznego pozyskiwania nowych klientów w segmencie mikroprzedsiębiorstw w warunkach, w których konkurenci często oferują nowsze i lepsze produkty, i usługi bankowe.

Przedmiotem analizy jest sytuacja banków spółdzielczych w obsłudze segmentu mikroprzedsiębiorstw. Przez pozycję konkurencyjną rozumiemy „osiągnięty przez przedsiębiorstwo wynik konkurowania $\mathrm{w}$ danym segmencie, rozpatrywany na tle wyników osiaganych przez konkurentów, innymi słowy - miejsce na skali korzyści, jakich przedsiębiorstwo dostarcza swoim interesariuszom, W porównaniu z miejscami zajmowanymi przez konkurentów" [Stankiewicz 2008]. W tym ujęciu istotą konkurencyjności banku spółdzielczego jest umiejętność funkcjonowania i rozwoju w warunkach konkurencji rynkowej [Gorynia i Łaźniewska 2010].

Źródło danych empirycznych stanowiły wyniki ogólnopolskich badań zrealizowanych na reprezentatywnej ze względu na obroty, branżę, zatrudnienie i województwo próbie $\mathrm{N}=800$ przedsiębiorców. Wyniki badań zaprezentowano w raporcie TNS Polska Firmy w świecie finansów 2016. Badanie obejmowało mikroprzedsiębiorstwa będące podmiotami o zatrudnieniu nieprzekraczającym 10 pracowników oraz rocznych obrotach nieprzekraczających 2 milionów euro w roku poprzedzającym rok realizacji badania. Realizację badań wykonał TNS w I kwartale 2016 roku metodą wywiadów telefonicznych wspomaganych komputerowo CATI. W analizach zastosowano agregowany indeks satysfakcji TRIM, przeprowadzono klasyfikację typologiczną klientów banków ze względu na ich postawy wobec banków oraz z wykorzystaniem analizy korespondencji zidentyfikowano podstawowych konkurentów banków spółdzielczych. 


\section{Wyniki badań}

\section{Udziały rynkowe banków spółdzielczych w obsłudze mikroprzedsiębiorstw}

Pozycja rynkowa przedsiębiorstwa może być mierzona udziałem na rynku oraz zdolnością utrzymywania bądź zwiększania tego udziału [Walczak 2009]. Według Centralnej Ewidencji Działalności Gospodarczej liczba aktywnych mikroprzedsiębiorstw w Polsce 2016 roku była szacowana na niespełna 2 mln podmiotów. W tej grupie $45 \%$ podmiotów aktywnie korzysta z kredytu w rachunku bieżącym, $20 \%$ ma zaciągnięte kredyty obrotowe, a $18 \%$ spłaca kredyty inwestycyjne.

Udział banków spółdzielczych mierzony odsetkiem obsługiwanych mikro przedsiębiorstw wynosił w IV kwartale 2016 roku 15\% (rys. 1). Jest to pozycja zbliżona do Banku Pekao SA, Banku Zachodniego WBK, ING Banku Śląskiego oraz nieznacznie ustępująca PKO Bankowi Polskiemu z udziałem wynoszącym $22 \%$. Banki spółdzielcze, jako całość sektora spółdzielczego są w czołówce banków obsługujących mikroprzedsiębiorstwa. Jednak poziom znajomości spontanicznej marki banku spółdzielczego wynosi $17 \%$, czyli tyle ile udział rynkowy banków spółdzielczych w rynku obsługi mikroprzedsiębiorstw. Oznacza to, że $17 \%$ ogółu badanych mikroprzedsiębiorców spontanicznie wymieniło markę banku spółdzielczego. Upraszczając tę ocenę można stwierdzić, że markę banku

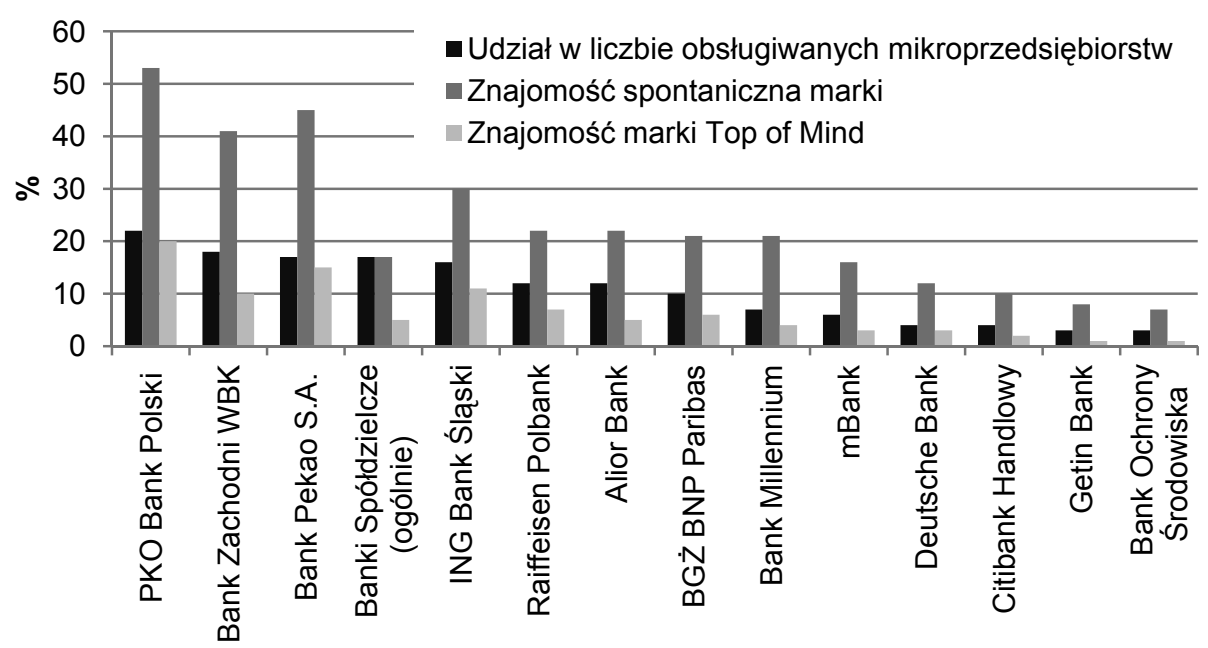

\section{Rysunek 1}

Udziały rynkowe banków oraz znajomość marek banków w segmencie mikroprzedsiębiorstw w 2016 roku

Źródło: Firmy w świecie finansów [2016]. 
spółdzielcze wymieniają spontanicznie tylko ci przedsiębiorcy, którzy korzystają ich usług. Jeszcze gorzej wypada ocena poziomu znajomości marki „Top of Mind” (czyli marki wskazanej spontanicznie jako pierwszej), która w przypadku banków spółdzielczych wynosi 5\%. Oznacza to, że nie więcej niż jedna czwarta klientów banków spółdzielczych zapytana o to, jakie zna marki banków obsługujących przedsiębiorstwa, wskazała, jako pierwszą markę banku spółdzielczego.

Udział rynkowy, czyli odsetek obsługiwanych podmiotów z ogółu mikropodmiotów działających na rynku nie jest jednak pełnym obrazem, gdyż dla 16\% mikropodmiotów obsługiwanych przez banki spółdzielcze są one tylko bankiem dodatkowym, a nie bankiem głównym. Średnia dla rynku wynosi $22 \%$ co oznacza, że przeciętnie każdy z banków obsługujących mikropodmioty ma w swoim portfolio około $1 / 5$ klientów, dla których jest tylko bankiem dodatkowym.

Banki spółdzielcze udzieliły $17 \%$ z liczby wszystkich kredytów obrotowych oraz $20 \%$ z liczby wszystkich kredytów inwestycyjnych, jakie w 2016 roku spłacali mikroprzedsiębiorcy (rys. 2). Te statystyki pozwalają stwierdzić, że banki spółdzielcze mają pozycję lidera w obsłudze kredytowej mikroprzedsiębiorstw. Żaden z banków komercyjnych nie ma większego udziału w liczbie kredytów udzielonych mikroprzedsiębiorstwom niż banki spółdzielcze. Należy jednak pamiętać, iż udziały te są mierzone liczbą udzielonych kredytów, a nie ich wartością.

W ujęciu wartościowym udział banków spółdzielczych w wartości udzielonych kredytów dla MSP w 2016 roku wynosił niespełna 10\%, czyli znacznie mniej niż w liczbie udzielonych kredytów [Komisja Nadzoru Finansowego 2016]. Jednocześnie banki spółdzielcze mają 38\% udziału w liczbie placówek

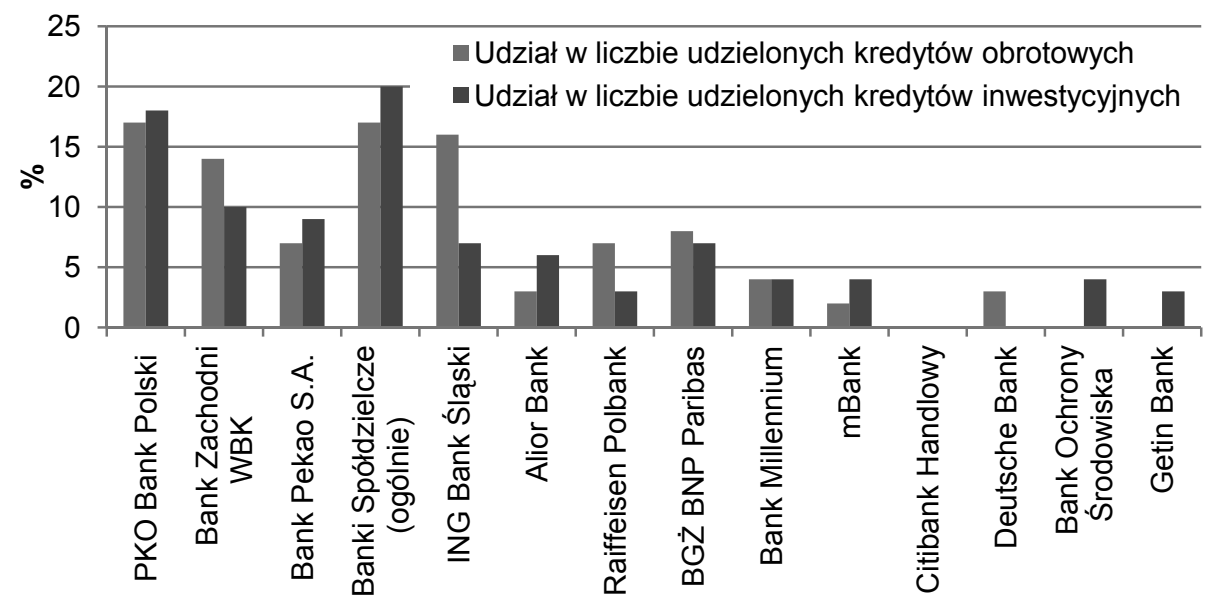

\section{Rysunek 2}

Udziały banków w liczbie kredytów spłacanych przez przedsiębiorstw mikro w 2016 roku Źródło: Firmy w świecie finansów [2016]. 
bankowych w całym sektorze bankowym, 19,7\% w liczbie osób zatrudnionych oraz $9,1 \%$ udziału w aktywach sektora bankowego. Statystyki te wskazuja, iż pozycja rynkowa banków spółdzielczych jest nieadekwatna do potencjału, jaki posiadają [Zygierewicz 2012].

\section{Wizerunek i preferencje wobec marki}

Wizerunek jest efektem długoletniej strategii jego kreowania, zmierzającej do ugruntowania lub zmiany postawy, przekonań, decyzji adresatów działań marketingowych podmiotu, stanowi realną percepcję i projekcję budowania przewagi konkurencyjnej [Szwacka-Mokrzycka 2010].

W literaturze przedmiotu jest niewiele miejsca poświęcono zagadnieniom związanym z wizerunkiem banków spółdzielczych, jednak na podstawie przeprowadzonych badań marka tych banków ma ograniczone możliwości kreowania przewagi konkurencyjnej w przyszłości. O sile marki świadczą między innymi preferencje dotyczące jej ponownego wyboru. Wśród ogółu mikroprzedsiębiorców marka banku spółdzielczego jest jedną z najmniej preferowanych marek w sytuacji, gdyby mieli dokonać zmiany dotychczasowego banku na inny. Zaledwie $4 \%$ z ogółu mikroprzedsiębiorców korzystających z usług innych banków niż banki spółdzielcze rozważałoby skorzystanie z usług banków spółdzielczych. Z kolei wśród mikroprzedsiębiorców obecnie korzystających z usług banków spółdzielczych tylko $28 \%$ w sytuacji ponownego wyboru, jako pierwszą preferowałoby markę banku spółdzielczego. Jest to jednoczenie najniższy wynik spośród wszystkich innych marek banków oferujących usługi dla mikroprzedsiębiorstw (średnia dla rynku wynosi 45\%), a 66\% mikroprzedsiębiorców obecnie korzystających z banków spółdzielczych rozważałoby ponowne skorzystanie $\mathrm{z}$ ich usług, jako jednej z trzech marek, które braliby pod uwagę. Pozostali ( $6 \%$ z obecnych klientów banków spółdzielczych) w ogóle nie bierze pod uwagę ponownego skorzystania $\mathrm{i}$ ich usług. W ramach rozważanych przez mikroprzedsiębiorców marek konkurencyjnych wobec banków spółdzielczych są: BZ WBK, Bank Pekao SA, PKO Bank Polski, BGŻ BNP Paribas oraz ING Bank Śląski. Dla klientów preferujących te banki kluczowe we współpracy są: niskie koszty współpracy z bankiem, jasne warunki współpracy, indywidualne podejście do firmy, dotrzymanie obietnic, mało formalności oraz wspieranie decyzji firmy, a głównym powodem powstrzymującym przed rozpoczęciem korzystania $\mathrm{z}$ ich usług jest brak placówki danego banku w okolicy.

Częściowo wyjaśnienia dużych udziałów rynkowych w liczbie obsługiwanych przedsiębiorstw i jednocześnie niskiej skłonności do ponownego wyboru marki można odszukać w powodach korzystania z usług danego banku, jakie 
podają mikroprzedsiębiorcy (rys. 3). Istnieje wyraźna różnica w deklarowanych przez mikroprzedsiębiorców powodach korzystania z usług danego banku. W grupie klientów banków spółdzielczych główne powody korzystania z ich usług skupiają się na bliskości placówki (57\%) oraz ofercie banku (29\%). W przypadku klientów banków komercyjnych powody korzystania są bardziej zróżnicowane, a najważniejszym jest oferta banku (40\% wskazań), następnie bliskość placówki (22\%), dobre opinie o banku wśród znajomych (14\%) oraz posiadanie prywatnego konta $\mathrm{w}$ tym banku (11\% wskazań).

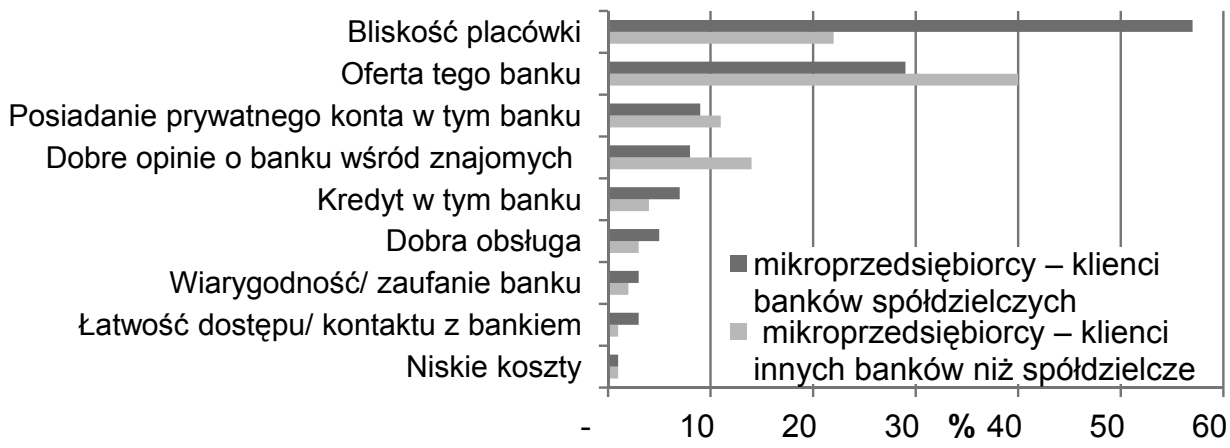

\section{Rysunek 3}

Deklarowane przez przedsiębiorstwa mikro powody korzystania z usług danego banku w grupie klientów banków spółdzielczych oraz klientów innych banków w 2016 roku [\%] Źródło: Firmy w świecie finansów [2016].

Mizerski [2008] sugeruje, że klienci w procesie wyboru banków kierują się obiegową opinią o nich, czyli word-of-mouth, a opinia ta stanowi jeden z najważniejszych składników wizerunku banku. Bankom spółdzielczym stosunkowo trudno wzmacniać pozycję rynkową wśród potencjalnych klientów w obszarze wizerunku. W literaturze zwraca się uwagę na kwestie kreowania wizerunku za pomocą takich narzędzi jak system identyfikacji wizualnej, komunikacja, jakość obsługi oraz działania public relations [Rodzinka i Tworzydło 2000]. $\mathrm{W}$ ich efekcie w obszarze czynników emocjonalnych $65 \%$ z ogółu badanychmikroprzedsiębiorców deklaruje, że współpraca z bankiem spółdzielczym nie jest prestiżowa, $61 \%$ twierdzi wprost, że nie lubi banków spółdzielczych, $59 \%$ ocenia, że banki spółdzielcze nie wprowadzają nowości. Jednak $61 \%$ z tej samej grupy przedsiębiorców ocenia, że banki spółdzielcze są partnerem dla firm, że dotrzymują obietnic, $56 \%$ podkreśla, że banki spółdzielcze mają proste i jasne zasady współpracy. Wśród czynników funkcjonalnych zdaniem 59\% banki spółdzielcze są tanie, a w opinii 63\% mikroprzedsiębiorców banki spółdzielcze każdej firmie proponują to samo. 
Banki spółdzielcze mają wyraźny i ukonstytuowany profil wizerunkowy wśród mikroprzedsiębiorców (rys. 4). Postrzegane są przede wszystkim, jako te, które mają niskie koszty usług, jako banki oferujące proste i jasne warunki współpracy, banki które doceniają klientów, które są wiarygodne i godne zaufania oraz mają szeroką sieć oddziałów. Pod względem wymienionych cech banki spółdzielcze w ocenach mikroprzedsiębiorców wyróżniają się pozytywnie na tle banków komercyjnych. Obszary wizerunkowo deficytowe dla banków spółdzielczych to: dobra bankowość elektroniczna, specjalizacja w obsłudze firm, wspieranie decyzji firm, szeroka oferta, innowacyjność, sieć bankomatów, prestiż. Jednak w przypadku tych deficytowych cech Twaróg ocenia, że problemem nie jest faktyczny ich brak, a to, że przedsiębiorcy nie wiedzą o tym, że banki spółdzielcze oferują nowoczesne rozwiązania, potrafią wspierać rozwój firm, są innowacyjne [Twaróg 2013].

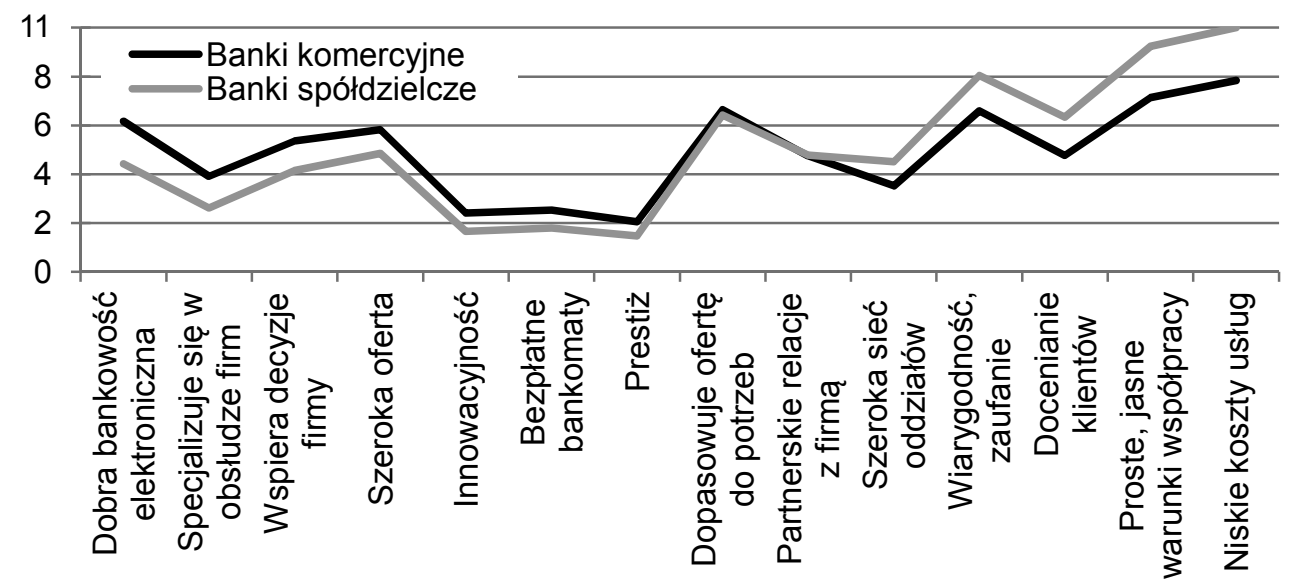

\section{Rysunek 4}

Profil wizerunkowy banków spółdzielczych oraz banków komercyjnych w opinii mikroprzedsiębiorców (oceny średnie na skali 0-11, gdzie ocena 0 oznacza w ogóle nie pasuje do ocenianej marki banku, a ocena 11 oznacza doskonale pasuje do ocenianej marki banku).

Źródło: Firmy w świecie finansów [2016].

Analizując migracje klientów, przeciętnie w okresie roku poprzedzającego datę realizacji badania wśród ogółu klientów rezygnujących z usług danego banku 9\% stanowili klienci banków spółdzielczych. Jednocześnie wśród ogółu klientów, którzy nawiązali współpracę z nowym bankiem, 6\% zdecydowało się na skorzystanie z usług banków spółdzielczych.

Wśród ogółu powodów zmiany banku $60 \%$ było po stronie banku, z którego usług, którego zrezygnował przedsiębiorca, a $40 \%$ przypadało na działania banków konkurencyjnych. Wśród czynników zniechęcających do kontynuacji 
korzystania z banku należą: niedocenianie wieloletnich klientów, niedogodności we współpracy z bankiem, niezadowolenie z bankowości elektronicznej, niezadowolenie z obsługi przez doradcę $\mathrm{w}$ banku, utrata zaufania do baku. Wśród czynników zachęcających do zmiany banku ze strony banków konkurencyjnych należą: polecenie innego banku przez kontrahenta, lepsza oferta $\mathrm{w}$ innym banku oraz możliwość lub łatwość uzyskania kredytu w innym banku [Firmy w świecie finansów 2016].

Wcześniej zaprezentowane statystyki uzasadniają opinię Perek i Pawlonki zgodnie, z którą konieczne jest podejmowanie przez banki spółdzielcze działań informacyjnych zmierzających do stworzenia wizerunku banków nowoczesnych, oferujących usługi, które sprostają wymaganiom przedsiębiorców. Widoczna jest potrzeba silniejszej integracji banków spółdzielczych w zakresie zarządzania wizerunkiem i budowania dhugofalowej strategii działania całego sektora bankowości spółdzielczej [Perek i Pawlonka 2014]. Odpowiedzią na te działania może być także zmiana niekorzystnej pod względem stażu struktury klientów. $Z$ usług banku spółdzielczego od 10 lat lub więcej korzysta 66\% mikroprzedsiębiorców. W przypadku banków komercyjnych $43 \%$ ich klientów ma staż ponad 10 lat. Jedynie 13\% klientów banków spółdzielczych korzysta z ich usług nie dłużej niż 5 lat, dla banków komercyjnych ta statystyka wynosi 28\% [Firmy w świecie finansów 2016].

\section{Satysfakcja klientów}

Satysfakcja klientów i ich postawa wobec banku, z którego korzystają jest jedną z kluczowych miar pozycji konkurencyjnej [Gołąb-Andrzejak i Badzińska 2015]. Mikroprzedsiębiorcy korzystający z usług banków spółdzielczych są zadowoleni ze standardu usług świadczonych przez banki spółdzielcze. Stosując do pomiaru agregowany indeks satysfakcji klientów TRIM, banki spółdzielcze zajmują drugą pozycję pod względem satysfakcji klientów, pozostając w czołówce z takimi markami jak ING Bank Śląski, czy też Alior Bank. Ranking wartości indeksu satysfakcji TRIM ${ }^{1}$ przedstawia się następująco: ING Bank Śląski 77 pkt, banki spółdzielcze 75 pkt, mBank 73 pkt, Bank Millennium 71 pkt, Alior Bank 70 pkt, Raiffeisen Polbank 69 pkt, Bank Pekao SA 66 pkt, Bank Zachodni WBK 65 pkt, BGŻ BNP Paribas 61 pkt, Deutsche Bank 60 pkt, PKO BP 60 pkt [Firmy w świecie finansów 2016]. W świetle tych statystyk zasadne jest pytanie stawiane przez Twaroga: Czy potencjalni klienci o tym wiedzą? [2013].

Uzupełnieniem ogólnego indeksu satysfakcji jest klasyfikacja typologiczna klientów banków ze względu na postawę wobec banku. W tym ujęciu możemy wyodrębnić cztery segmenty mikroprzedsiębiorców. 1) Apostołowie: zaangażo-

\footnotetext{
${ }^{1}$ Więcej o indeksie TRIM, http://www.tnsglobal.com/business-information/stakeholder-relationship-management/, [dostęp: 26.09.2017].
} 


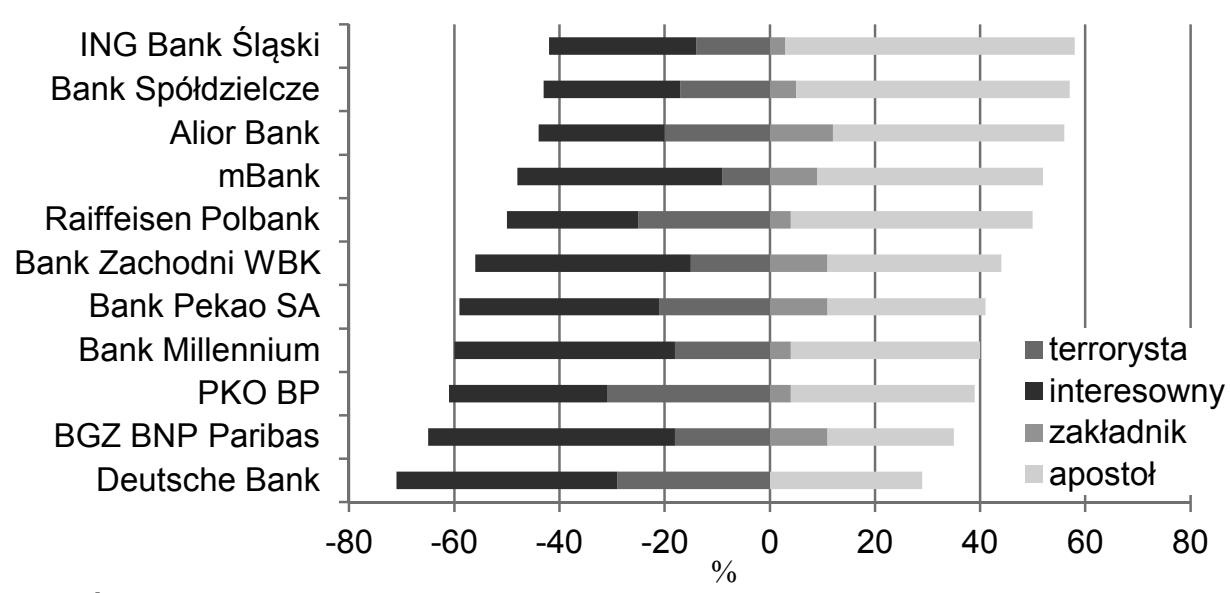

\section{Rysunek 5}

Klasyfikacja typologiczna mikroprzedsiębiorców ze względu na ich satysfakcję oraz postawę wobec banku, z którego korzysta ich przedsiębiorstwo.

Źródło: Firmy w świecie finansów [2016].

wani, emocjonalnie związani z marką banku, rozpowszechniają pozytywną opinię na temat banku, duże szanse powodzenia strategii up-sellingu i cross-sellingu. 2) Zakładnicy: kontynuują współpracę $z$ bankiem mimo niskiej satysfakcji, istnieje bariera przejścia uniemożliwiająca zmianę banku, mimo swego przywiązania, mogą być uciążliwi dla banku ze względu na ich niską satysfakcję. 3) Terroryści: mają złe doświadczenia z bankiem, rozpowszechniają złą opinię na jego temat, prawdopodobieństwo rezygnacji z usług banku jest wysokie. 4) Interesowni: podążają za okazjami, są krótkookresowo zainteresowan daną ofertą (np. kredytu, depozytu itp.), są to klienci drodzy w pozyskaniu (koszt promocji i reklamy), a jednocześnie podatni na odejście. Przeciętnie na rynku „Apostołowie” stanowią 39\%, ,Interesowni” 33\%, ,Zakładnicy” 7\% oraz ,,Terroryści" 21\% [Firmy w świecie finansów 2016].

W przypadku segmentacji mikroprzedsiębiorców będących klientami banków spółdzielczych 52\% to „Apostołowie”, 5\% to „Zakładnicy”, 26\% „Interesowni” oraz 17\% ,Terroryści”. Uwagę zwraca, że to właśnie banki spółdzielcze mają największy (poza ING Bank Śląski) odsetek „Apostołów” i jednocześnie jeden z najniższych odsetek ,Zakładników” i „Interesownych”.

Konstatacja powyższych prawidłowości sprawia, iż nadal aktualne pozostaje hasło głoszone przez liderów bankowości spółdzielczej: „Jesteśmy dobrzy, ale kto o tym wie?" [Mruk 2007, Twaróg 2013, Perek i Pawlonka 2014]. 


\section{Podsumowanie}

Dokonując podsumowania pozycji rynkowej banków spółdzielczych w badanych obszarach, należy stwierdzić, że specyfika ich dotychczasowej działalności pozwoliła na zajęcie mocnej pozycji w obsłudze mikroprzedsiębiorstw. Banki spółdzielcze zdobyły ważny i ceniony kapitał reputacyjny, a ich aktualni klienci doceniają jakość usług.

$\mathrm{Na}$ podstawie przeprowadzonych badań można stwierdzić, iż banki spółdzielcze nie wykorzystują $\mathrm{w}$ pełni własnych walorów w budowaniu przewagi konkurencyjnej.

Wysoki udział w liczbie obsługiwanych przedsiębiorstw banki spółdzielcze zawdzięczają stabilnej bazie „starych” klientów. Banki spółdzielcze nie są brane pod uwagę, jako banki preferowane przez potencjalnych klientów, a w perspektywie istnieje poważne ryzyko utracenia obecnej pozycji rynkowej.

Konkurencyjna pozycja wynika z niszowych obszarów, w których działają banki spółdzielcze, z kosztów obsługi postrzeganych, jako niskie oraz z emocjonalnych uwarunkowań działania na lokalnym runku.

Rosnąca konkurencja sprawia, że stosowanie narzędzi marketingowych jest nieuniknione i powinno stać się elementarną częścią wspomagania funkcjonowania banków spółdzielczych. Punktem wyjścia powinna być przynajmniej podstawowa ocena obszarów konkurencji takich jak: profil klientów i jego atrakcyjność, produkty bankowe, stopień ich zróżnicowania i atrakcyjność, intensywność i charakter działań marketingowych, postrzeganie społeczne - image, zaawansowanie technologiczne, potencjał kapitałowy i jego stabilność.

Banki spółdzielcze działają pod silną presją spadającej marży odsetkowej. Ze względu na ograniczoną skalę działania nie mogą sobie zrekompensować spadających dochodów odsetkowych wzrostem obrotów. Powstaje więc zagrożenie dla ich wyników finansowych i dalszego rozwoju. Przeciwstawienie się tym niekorzystnym tendencjom stanowi wielkie wyzwanie dla banków spółdzielczych, któremu muszą stawić czoła. Banki spółdzielcze powinny odpowiedzieć sobie przynajmniej na kilka pytań:

1. Kim są i będą adresaci usług banków spółdzielczych, jaki jest ich potencjał ekonomiczny?

2. W jakich segmentach klientów banki spółdzielcze zyskują a w jakich traca swoją pozycję rynkową?

3. Czy banki spółdzielcze w pełni wykorzystują własne walory w budowaniu przewag konkurencyjnych?

4. Na jakim polu banki spółdzielcze mogą szukać szansy na zwiększenie atrakcyjności wśród potencjalnych klientów? 
5. Czy z perspektywy klienckiej kierunek rozwoju banków spółdzielczych jest słuszny?

6. Jak z perspektywy klienckiej wypada polska bankowość spółdzielcza na tle polskiej bankowości komercyjnej?

7. Jakie działania są priorytetem dla rozwoju zgodnego z założeniami spółdzielczości, a jednocześnie potrzebami zgłaszanymi przez obecnych i potencjalnych klientów?

Ważnym źródłem przewagi konkurencyjnej banków spółdzielczych są ich pracownicy. Wielu z nich może wykazać się długim stażem i przez to bogatym doświadczeniem zawodowym. Pracownicy banków spółdzielczych utrzymują bliskie relacje ze swoimi klientami, dobrze znają ich potrzeby i oczekiwania. Podchodzą do nich indywidualnie, ponieważ żyją i pochodzą z tego samego środowiska, co ich klienci. Banki spółdzielcze obecnie ponoszą duże nakłady na najnowsze rozwiązania informatyczne, usprawniające zarządzanie bankiem i umożliwiające klientom korzystanie $\mathrm{z}$ bankowości internetowej oraz mobilnej. Atutem banków spółdzielczych jest ich indywidualny charakter, dzięki czemu mogą oferować klientom produkty „skrojone na miarę”, po cenach uwzględniających lokalne uwarunkowania ekonomiczne. Są to uwarunkowania, które umiejętnie wykorzystane mogą stanowić przesłanki do sukcesu w przyszłości.

\section{Literatura}

Firmy w świecie finansów 2016: TNS Polska, Warszawa

GOŁĄB-ANDRZEJAK E., BADZIŃSKA E., 2015: Satysfakcja klientów, jako źródło sukcesu organizacji - studium przypadku. Zeszyty Naukowe Uniwersytetu Szczecińskiego 875, Problemy Zarządzania, Finansów i Marketingu 41, 1, 81-91.

GORYNIA M., ŁAŹNIEWSKA E., 2010: Kompendium wiedzy o konkurencyjności, Wydawnictwo Naukowe PWN, Warszawa, 41, 48-50.

HARASIM J., 2009: Zasoby niematerialne a konkurencyjność banku i jego efektywność, [w:] Harasim J. (red.). Konkurencyjność i efektywność działania banku-podejście zasobowe. Prace Naukowe AE w Katowicach, Katowice, 81-104.

IDZIK M.: 2016: Lokalne instytucje finansowe w procesie budowania wspólnot społecznych, Wystapienie podczas Forum Liderów Banków Spółdzielczych, Warszawa.

IDZIK M.: 2015: Selected Aspects of the Situation of the Cooperative Banks on the Retail Banking Market. Roczniki Naukowe SERiA, 14, 6, 89-94,

KASIEWICZ S., KURLIŃSKI L., MARCINKOWSKA M., 2013: Sektor bankowy-motor czy hamulec wzrostu gospodarczego?, Warszawski Instytut Bankowości, Warszawa, 63-81.

KOMISJA NADZORU FINANSOWEGO, 2013: Analiza sytuacji bankowego sektora spótdzielczego, w tym funduszy własnych, $w 2012$ roku oraz informacja o przebiegu prac nad możliwymi modelami działania zrzeszeń w kontekście Dyrektywy CRD IV oraz Rozporzadzanie CRR, Warszawa, 
MEERMAN SCOTT D., 2012: Marketing i PR w czasie rzeczywistym: jak blyskawicznie dotrzeć do rynku i nawiazać kontakt z klientem, Wolters Kluwer Polska, Warszawa, $121-124$.

MIZERSKI G., 2008: Opiniq w bank, Gazeta Bankowa 34, Warszawa.

MONITOR BANKOWY 01'2017, ZBP, Warszawa.

MRUK H., 2007: Wieniec bez chwaty, Puls Biznesu 2, z dn. 03.01.2007.

NOWACKA A., 2009: Uwarunkowania komunikacji marketingowej na przykładzie banków spółdzielczych powiatu płockiego i płońskiego, Szkoła Główna Gospodarstwa Wiejskiego, Warszawa (rozprawa doktorska maszynopis), 83.

PAWLONKA T., 2012: Sytuacja ekonomiczna banków spółdzielczych w latach 2000-2011, Zeszyty Naukowe Szkoły Głównej Gospodarstwa Wiejskiego w Warszawie. Ekonomika i Organizacja Gospodarki Żywnościowej, nr 97, 183-192.

PEREK A., PAWLONKA T., 2014: Rozpoznawalność banków spółdzielczych w segmencie młodych konsumentów, Zeszyty Naukowe Szkoły Głównej Gospodarstwa Wiejskiego w Warszawie. Ekonomika i Organizacja Gospodarki Żywnościowej 106, Warszawa, $71-83$.

RODZINKA J., TWORZYDŁO D., 2000: Wizerunek banku komercyjnego w perspektywie doświadczeń minionej dekady, Zeszyty Naukowe Wyższej Szkoły Informatyki i Zarządzania 4, 131-145.

SIUDEK T., SNARSKI P., CHODERA B., 2013: Konkurencyjność banków komercyjnych i spółdzielczych w Polsce. Roczniki Ekonomii Rolnictwa i Rozwoju Obszarów Wiejskich 100, 2, 25-36.

STANKIEWICZ M.J., 2008: Istota i sposoby oceny konkurencyjności przedsiębiorstwa, [w:] Gospodarka Narodowa, 7-8, 87-89.

SZAMBELANCZYK J., 2016: Rola banku zrzeszajacego w nowej strukturze. Wystapienie podczas Forum Liderów Banków Spółdzielczych, Warszawa.

SZELĄGOWSKAA., 2012: Współczesna bankowość spółdzielcza. Wydawnictwo CeDeWu, Warszawa, 18-37.

SZWACKA-MOKRZYCKA J., 2010: Znaczenie wizerunku w budowaniu pozycji konkurencyjnej banków, Zeszyty Naukowe Szkoły Głównej Gospodarstwa Wiejskiego. Polityki Europejskie, Finanse i Marketing 4 (53), Warszawa, 278-286.

TWARÓG E., 2013: Nowoczesny jak... bank spółdzielczy, Puls Biznesu.pl, z dn. 06.02.2013.

WALCZAK W., 2009: Niematerialne determinanty konkurencyjności wspótczesnych przedsiębiorstw, [w:] S. Lachiewicz, M. Matejun, (red.), Konkurencyjność, jako determinanta rozwoju przedsiębiorstwa, Wydawnictwo Politechniki Łódzkiej, 112-119.

WĘCŁAWSKI J., 2010: Banki spółdzielcze w konkurencyjnym otoczeniu. Annales Universitatis Mariae Curie-Skłodowska XLIV, sectio H, 231-248.

WOŹNIEWSKA G., 2010: Analiza potencjału konkurencyjności banku spółdzielczego - zarys koncepcji. Annales Universitatis Mariae Curie-Skłodowska XLIV, 2 sectio H, 325-338.

WOŹNIEWSKA G., 2011: Potencjał konkurencyjności banku spółdzielczego, Wydawnictwo UE we Wrocławiu, Wrocław, 73-86.

ZYGIEREWICZ M., 2012: Sytuacja ekonomiczna banków spółdzielczych i ich kondycja na tle konkurencji komercyjnej, [w:] A. Szelągowska (red.) Wspótczesna Bankowość Spótdzielcza, Wydawnictwo CeDeWu, Warszawa, 187. 


\section{Abstrakt}

Celem opracowania była ocena pozycji konkurencyjnej banków spółdzielczych oraz ich zdolności do kreowania tendencji rozwojowych i skutecznego pozyskiwania nowych klientów w segmencie mikroprzedsiębiorstw. Źródło danych empirycznych stanowiły wyniki ogólnopolskich badań zrealizowanych na reprezentatywnej próbie $\mathrm{N}=800$ przedsiębiorstw o zatrudnieniu do 10 pracowników oraz rocznych obrotach do $2 \mathrm{mln}$ euro. Analiza objęto udziały rynkowe, znajomość, potencjał i wizerunku marki oraz satysfakcję klientów. Banki spółdzielcze nie wykorzystują w pełni swoich walorów w budowaniu przewagi konkurencyjnej. Wysokie udziały rynkowe zawdzięczają stabilnej bazie „starych” klientów. Banki spółdzielcze nie są preferowane przez potencjalnych klientów. Pozycja konkurencyjna wynika z niszowych obszarów, w których działają banki spółdzielcze, kosztów obsługi oraz emocjonalnych uwarunkowań działania na lokalnym rynku. Stosowanie narzędzi marketingowych jest nieuniknione i powinno stać się elementarną częścią wspomagania funkcjonowania banków spółdzielczych.

Słowa kluczowe: bank spółdzielczy, przewaga konkurencyjna, wizerunek, satysfakcja, pozycja rynkowa

\section{Competitive position of the cooperative banks in the segment of micro-companies}

\section{Abstract}

The objective of this paper is to evaluate the competitive position of the cooperative banks and their ability to create the growth trends and effectively acquire new customers in the micro-company segment. The sources of the empirical data were the results of the nation-wide surveys conducted on a representative sample of $\mathrm{N}=800$ companies with up to 10 employees and an annual turnover of up to $2 \mathrm{~m}$ EUR. The analysis included the market shares, familiarity, brand potential and image as well as the customer satisfaction. The cooperative banks do not fully use their advantages in building their competitive advantage. A stable base of the "regular" customers contributes to their high market shares. The cooperative banks are not preferred by the prospective customers. The competitive position of the cooperative banks is based on the niche areas where the cooperative banks operate and the service costs as well as the emotional circumstances of operating on the local market. The application of the marketing tools is inevitable and should be the elementary part of the support provided for the cooperative banks.

Key words: cooperative bank, competitive advantage, image, satisfaction, market position 